\title{
Study on the flavonoids and pectin contents in different okra (Abelmoschus escullentus $L$.) accessions.
}

\author{
Shucan Liu', J Huang ${ }^{1}$, Meiling Li $^{1}$, Cheng Zhang', Jingjing Zhu',YanKe Zhao², Xinhong Guo ${ }^{1 *}$, \\ Jiazhuo Ye $^{3^{*}}$
}

${ }^{1}$ College of Biology, State Key Laboratory of Chemo/Biosensing and Chemometrics, Hunan University, Changsha, 410082, PR China

${ }^{2}$ Hunan University Library, Hunan University, 410082, PR China

${ }^{3}$ College of Electrical and Information Engineering, Hunan University, 410082, PR China

\begin{abstract}
Okra (Abelmoschus escullentus) is a cash crop with health care function. To determine the content of flavonoids and pectin, 7 accessions and diverse tissues were detected. The results showed that significant discrepancy was found among the 7 accessions and different tissues. The flowers of YGF and tender siliques of JQK had the highest level of flavonoids, reaching $2.56 \%$ and $2.03 \%$ respectively. Moreover, the content of pectin in the dry powder of KLB was the highest $(21.71 \%)$. The highest content of pectin was $\mathbf{1 8 . 8 9 \%}$ in the determination of the different fruit parts of MRZ, higher than that in leaves, seeds roots, et al. The data of flavonoids and pectin content was conducive to further development of okra in the field of medicine, food and agriculture.
\end{abstract}

Keywords: Okra, Flavonoids, Pectin.

Accepted on November 28, 2017

\section{Introduction}

Okra belongs to an annual herb of Malibaceae (Hibiscus Linn.), also known as okra, coffee okra. Okra is known as the goat angle in Guangzhou, China and known as Vietnamese sesame in Hunan. Its tender siliques are rich in protein, unsaturated fatty acids, minerals, alkaloids, free amino acids, sticky slippery juice and other bioactive ingredients. The Americans call it "plant Viagra" and the Japanese call it "green ginseng." Regular consumption of okra can make lower blood sugar, and prevent the liver, cardiovascular and intestinal diseases. It plays a significant role on great medicinal effect [1].

The flavonoids are a group of polyphenolic compounds [2]. Widely existing in plants, flavonoids which have a wide variety, pharmacological activity often combine with sugars into glycosides. Moreover, flavonoids play a significant role in the scavenging of free radicals and antioxidant. We call flavonoids as "phytoestrogens", because the function of flavonoids is similar to the estrogen in the human body [3]. It has a long history that flavonoids are ushed in the anticancer treatment process. The studies showed that it is mainly through the anti-free radical effects, inhibition of cancer cell growth and anti-cancer factor three ways to achieve anti-cancer. Lipid peroxidation of lipid cells would destroy genetics while the free radical enriched, resulting in cancer. However, flavonoids can inhibit the oxidation of lipid peroxidation process, reduce cell carcinogenesis. For example, quercetin in flavonoids can react with lipid peroxides (ROO) to inhibit lipid peroxidation [4].

Pectin is the most complex component of the molecular structure of the plant cell wall, and its content is about $35 \%$ of the cell wall of dicotyledonous plants [5]. In the Golgi apparatus, pectin is mainly composed of galacturonic acid polymerization, and then secreted to the plant cell wall and cell junction, indicating that pectin in addition to the cell wall as part of the cell division of proliferation. There are other functions like resistance to injury and pathogen invasion, involved in signal transduction, fixed metal ions, enzymes and growth factors. Pectin has the above functions to make it play an important role in plant growth and development and resistance to pests and diseases [6]. The pectin treatment of B16F10 melanoma cells can promote cancer cell apoptosis and inhibit its spread. Pectin and $\mathrm{PH}$, hot modified pectin has anticancer activity, indicating that pectin is a potential cancer treatment drugs [7-8]. As a soluble fiber, Okra with lower blood sugar, blood lipids and reduce cholesterol, improve immunity and other aspects of the effect [9].

\section{Materials and Methods}

\section{Plant Material and Treatments}

Plant materials were collected from various areas of China. JQK and YGF come from Hangzhou, Zhejiang Province. HQK comes from Jiaxing, Zhejiang Province. DJWJ comes from Weifang, Shandong Province. KLB and TWWF come from Wuxi Jiangsu Province. MRZ comes from Cangzhou Hebei Province. The flowers taken in experiment were just blooming flowers and the siliques and seeds were taken from the fifth day after the withering of the flowers. The leaves were the fourth leaf of the plant at the top of the plant. The stem was all the young part of the top, and the roots were from each mature 
Citation: Liu S, Huang J, Li M, et al. Study on the flavonoids and pectin contents in different okra (Abelmoschus escullentus L.) accessions. J

plant. Production of the standard curve used in the rutin is purchased in Shanghaiyuanye Biotechnology Limited Company. Anhydrous ethanol, $\mathrm{NaNO}_{2}, \mathrm{Al}\left(\mathrm{NO}_{3}\right)_{3}$ and $\mathrm{NaOH}$ were purchased from Sinopharm Group Chemical Reagent Co., Ltd. Semi-lactaldehyde was purchased from Dingguo Biotechnology Co., Ltd., concentrated $\mathrm{H}_{2} \mathrm{SO}_{4}$ for excellent grade pure, sodium hydroxide and ethanol solution are analytical grade.

\section{Determination of flavonoid contents}

For exploring the flavonoids contents of okra, $2.5 \mathrm{~g}$ the fresh okra tissue was taken for grinding into powder with liquid nitrogen (or dry product ground into powder and weight $0.5 \mathrm{~g}$ ). The powder were supplemented with $30 \mathrm{~mL} 70 \%$ ethanol solution, 70 water bath $2 \mathrm{~h}$, treated with cell crusher for 30 minutes. The filtrate was washed with $70 \%$ ethanol solution. The extract was filtered and the volume was set to $50 \mathrm{ml}$. The samples were treated by $\mathrm{NaNO}_{2}-\mathrm{Al}\left(\mathrm{NO}_{3}\right)_{3}$, flavonoids concentrations were determined by UV spectrophotometry using a standard curve made by standard rutin solutions, and the relative flavonoids concentrations were calculated and the absorbance was measured at $493 \mathrm{~nm}$.

\section{Determination of Pectin Contents}

In order to analyze the contents of Pectin from okra, $2.5 \mathrm{~g}$ fresh tissues of okra (or $0.5 \mathrm{~g}$ drying tissues) were weighed and were ground in liquid nitrogen for extraction of Pectin. The powder were soaked into $30 \mathrm{~mL} 70^{\circ} \mathrm{C}$ anhydrous ethanol, centrifuged with 4000rpm $15 \mathrm{~min}$. The sediments were washed with $67 \%$ ethanol solution in $85^{\circ} \mathrm{C}$ water-bath heating until the reaction of carbohydrate generation disappeared. The Absorbance of the extracted solution was measured at $525 \mathrm{~nm}$ with colorimetry of carbazole.

\section{Results}

\section{Standard Curve Drawing}

To draw the standard curve, rutin was treated with $\mathrm{NaNO}_{2}-$ $\mathrm{Al}\left(\mathrm{NO}_{3}\right)_{3}$ to make a series of standard solutions of concentration gradient, and absorbance was measured at $493 \mathrm{~nm}$. The standard curve was drawn with the concentration as the $\mathrm{X}$-axis and the absorbance as the $\mathrm{Y}$-axis. The regression equation is $y=10.497 x+0.0012, R 2=0.9991$ (Figure 1).

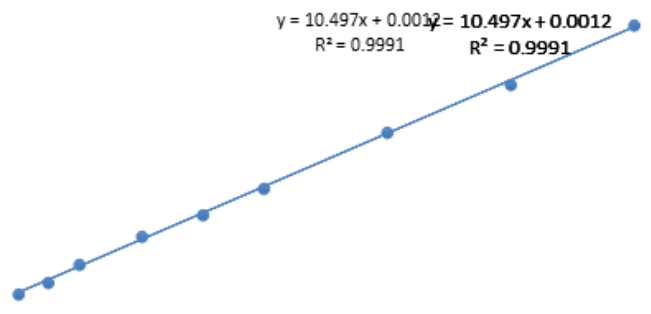

\section{Detection of Flavonoids Contents in Different Accessions of Okra}

Flavonoids are a component rich in okra, with anti-cancer, cardiovascular protection, lower blood sugar and a series of efficacy. For detecting the content of flavonoids in different accessions of okra, the dry powder samples were taken from fresh seven accessions of okra and dried in an oven at $50^{\circ} \mathrm{C}$ to constant weight, ground into a powder and weighed $0.5 \mathrm{~g}$. The samples were treated by $\mathrm{NaNO}_{2}-\mathrm{Al}\left(\mathrm{NO}_{3}\right)_{3}$, and the absorbance was measured at $493 \mathrm{~nm}$ by UV spectrophotometer, calculated the content of flavonoids. It can be seem that the highest flavonoid content of YGF in the selected flowers from 7 accessions was $2.56 \%$, and the lowest content of flavonoids was JQK, $1.47 \%$ (Table 1).

Table 1. Contents of flavonoids in different varieties of okra

\begin{tabular}{|c|c|c|c|c|}
\hline $\begin{array}{l}\text { Accessio } \\
\text { ns }\end{array}$ & Dry weight (g) & $\begin{array}{l}\text { Absorbance } \\
\text { (A) }\end{array}$ & $\begin{array}{l}\text { The total } \\
\text { content of } \\
\text { flavonoids } \\
\text { (mg) }\end{array}$ & $\begin{array}{l}\text { The content } \\
\text { of flavonoids } \\
(\%)\end{array}$ \\
\hline TWWF & 0.5008 & 0.169 & 7.992759836 & 1.5959984 \\
\hline KLB & 0.5011 & 0.174 & 8.230923121 & 1.642571 \\
\hline YGF & 0.4961 & 0.268 & 12.70839287 & 2.5616595 \\
\hline DJWJ & 0.5014 & 0.197 & 9.326474231 & 1.8600866 \\
\hline JQK & 0.5006 & 0.156 & 7.373535296 & 1.4729395 \\
\hline MRZ & 0.5012 & 0.201 & 9.517004859 & 1.8988437 \\
\hline HQK & 0.4995 & 0.222 & 10.51729065 & 2.1055637 \\
\hline
\end{tabular}

As the Flavonoids has a variety of effects on the human body, and the tender siliques are also important parts of the edible, so the different accessions of tender siliques were tested (Table 2). The results showed that the highest content of flavonoids in the tender siliques was JQK, $2.03 \%$, and the lowest content of KLB was only $1.19 \%$, indicating that tender siliques of JQK were the best part for the edible.

Table 2. Contents of flavonoids in tender siliques of different accessions of okra

\begin{tabular}{lllll}
\hline $\begin{array}{l}\text { Accession } \\
\mathrm{s}\end{array}$ & Dry weight $(\mathrm{g})$ & $\begin{array}{l}\text { Absorbance } \\
(\mathrm{A})\end{array}$ & $\begin{array}{l}\text { The total content } \\
\text { of flavonoids } \\
(\mathrm{mg})\end{array}$ & $\begin{array}{l}\text { The content of } \\
\text { flavonoids }(\%)\end{array}$ \\
\hline TWWF & 0.4867 & 0.151 & 7.135372011 & 1.466071915 \\
\hline KLB & 0.4955 & 0.125 & 5.89692293 & 1.190095445 \\
\hline YGF & 0.5103 & 0.142 & 6.706678099 & 1.314261826 \\
\hline DJWJ & 0.5007 & 0.157 & 7.421167953 & 1.482158569 \\
\hline JQK & 0.4984 & 0.214 & 10.1362294 & 2.033753892 \\
\hline MRZ & 0.5112 & 0.197 & 9.326474231 & 1.824427666 \\
\hline HQK & 0.4992 & 0.186 & 8.802515004 & 1.76332432 \\
\hline
\end{tabular}

Figure 1. Standard curve of Rutin 


\section{Determination of Flavonoids in Different Tissues}

In addition, different tissue sites of the MRZ were tested by the above method (Table 3). The content of flavonoids in tender seeds reached $3.12 \%$, tender leaves followed by $2.67 \%$. The content of flavonoids in mature roots and stems was low, only $0.87 \%$ and $0.53 \%$, respectively. The high content of flavonoids in leaves may have the effect of chlorophyll, since chlorophyll is soluble in ethanol solution. In the extraction process may have chlorophyll affect the UV detection.

Table 3. Contents of flavonoids in different tissues

\begin{tabular}{lllll}
\hline Tissues & $\begin{array}{l}\text { Dry } \\
\text { weight }(\mathbf{g})\end{array}$ & $\begin{array}{l}\text { Absorbance } \\
(\mathbf{A})\end{array}$ & $\begin{array}{l}\text { The total } \\
\text { content of } \\
\text { flavonoids } \\
\text { (mg) }\end{array}$ & $\begin{array}{l}\text { The content of } \\
\text { flavonoids (\%) }\end{array}$ \\
\hline Roots & 0.1514 & 0.099 & 1.304372678 & 0.861540738 \\
\hline Stems & 0.1489 & 0.061 & 0.797561208 & 0.535635465 \\
\hline Leaves & 0.1496 & 0.302 & 4.011812899 & 2.681693114 \\
\hline Siliques & 0.1506 & 0.21 & 2.784795656 & 1.849133902 \\
\hline Seeds & 0.1492 & 0.352 & 4.678670096 & 3.135837866 \\
\hline Flowers & 0.1512 & 0.218 & 2.891492807 & 1.912362968 \\
\hline
\end{tabular}

\section{Drawing of Standard Curve of Galactose}

As the standard, galactose $(0.0 \mathrm{mg} / \mathrm{L}, 20.0 \mathrm{mg} / \mathrm{L}, 40.0 \mathrm{mg} / \mathrm{L}$, $60.0 \mathrm{mg} / \mathrm{L}, 80.0 \mathrm{mg} / \mathrm{L}$, and $100.0 \mathrm{mg} / \mathrm{L})$ was treated with carbazole, $98 \% \mathrm{H}_{2} \mathrm{SO}_{4}$. Absorbance was measured at $525 \mathrm{~nm}$. The standard curve was drawn with the concentration of galactose as the $\mathrm{X}$-axis and the absorbance as the Y-axis (Figure 2). The regression equation is $y=0.0072 x-0.0056, \mathrm{R} 2=$ 0.999 .

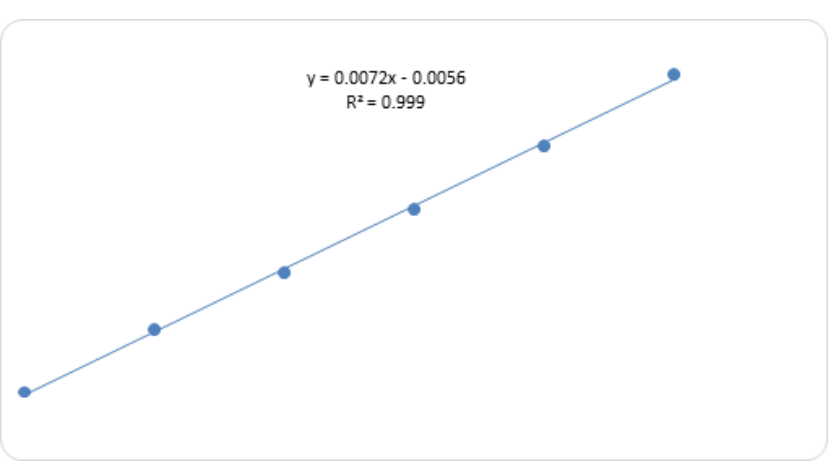

\section{Analysis of Pectin Contents in Different Accessions of Okra}

For analyzing the discrepancy of content between different accessions, tender siliques from 7 accessions of okra were collected, ground and weighed $0.5 \mathrm{~g}$ to use. Absorbance was measured at $525 \mathrm{~nm}$ after the extracting pectin treated with carbazole, $98 \% \mathrm{H}_{2} \mathrm{SO}_{4}$, the content of 7 accessions okra were calculated with the regression equation (Table 4). The results showed that the highest content of pectin in tender siliques of different okra accessions was KLB, 21.7\%.

Table 4. Contents of pectin in different strains of tender siliques

\begin{tabular}{|c|c|c|c|c|}
\hline Accessions & $\begin{array}{l}\text { Dry } \\
\text { weight }(g)\end{array}$ & $\begin{array}{l}\text { Absorbanc } \\
\text { e (A) }\end{array}$ & $\begin{array}{l}\text { The total } \\
\text { content of } \\
\text { pectin }(\mathrm{mg})\end{array}$ & $\begin{array}{l}\text { The content of } \\
\text { pectin }(\%)\end{array}$ \\
\hline TWWF & 0.514 & 0.481 & 84.47916667 & 16.43563554 \\
\hline YGF & 0.506 & 0.595 & 104.2708333 & 20.60688405 \\
\hline MRZ & 0.511 & 0.552 & 96.80555556 & 18.94433573 \\
\hline HQK & 0.518 & 0.533 & 93.50694444 & 18.05153368 \\
\hline DJWJ & 0.497 & 0.486 & 85.34722222 & 17.17247932 \\
\hline JQK & 0.52 & 0.476 & 83.6111111 & 16.07905983 \\
\hline KLB & 0.493 & 0.611 & 107.0486111 & 21.71371422 \\
\hline
\end{tabular}

\section{Determination and Analysis of Pectin Contents in Different Tissue}

To explore the discrepancy between different tissue, the mature roots, the top of the young stem and the young leaves, the flowers, the tender siliques and the mature siliques, the young seeds from MRZ were collected for pectin extraction. Furthermore, the content of pectin in the young tissue was higher than that in the mature tissue. According to the weight of these different tissue parts before and after drying, the moisture content was calculated. Then, the pectin contents of fresh tissues were used to calculate the theoretical pectin content of dry powder tissue pectin content. The highest theoretical content of pectin was the tender siliques, reached $19.3 \%$ (Table 5).

Figure 2. Standard Curve of Galactose

Table 5. Theoretical contents of pectin in different tissues

\begin{tabular}{lllll}
\hline Tissues & Fresh Weight $(\mathbf{g})$ & Dry weight $(\mathbf{g})$ & The content of water (\%) & Dry weight (\%) \\
\hline Roots & 21.5867 & 3.2024 & 85.1649395 & $\begin{array}{l}\text { Theoretical } \\
\text { pectin (\%) }\end{array}$ \\
\hline
\end{tabular}


Citation: Liu S, Huang J, Li M, et al. Study on the flavonoids and pectin contents in different okra (Abelmoschus escullentus L.) accessions. J Agric Sci Bot 2017;1(1):12-16.

\begin{tabular}{llllll}
\hline Stems & 6.512 & 0.8566 & 86.8458231 & 13.1541769 & 8.349542242 \\
\hline Leaves & 10.2931 & 2.055 & 80.03516919 & 19.96483081 & 5.704929522 \\
\hline Flowers & 12.1559 & 1.164 & 90.42440296 & 9.575597035 & 10.31890788 \\
\hline Tender siliques & 14.6155 & 1.3685 & 90.63665287 & 9.363347131 & 19.31363925 \\
\hline seeds & 8.1546 & 1.1912 & 85.39229392 & 14.60770608 & 9.852726513 \\
\hline Mature siliques & 12.1623 & 1.4735 & 87.88469286 & 12.11530714 & 8.57191831 \\
\hline
\end{tabular}

By comparing the direct detection of dry powder in different parts of the pectin content (Table 6), we found that the highest content of pectin also was the tender siliques, reached $18.9 \%$.

Table 6. Content of pectin in different tissues

\begin{tabular}{|c|c|c|c|c|}
\hline Tissues & $\begin{array}{l}\text { Dry } \\
\text { (g) }\end{array}$ & $\begin{array}{l}\text { Absorbance } \\
\text { (A) }\end{array}$ & $\begin{array}{l}\text { The total } \\
\text { content of } \\
\text { pectin }(\mathrm{mg})\end{array}$ & $\begin{array}{l}\text { Content of } \\
\text { pectin (\%) }\end{array}$ \\
\hline Roots & 0.2682 & 0.117 & 17.02777778 & 6.3489104 \\
\hline Stems & 0.2539 & 0.154 & 22.16666667 & 8.7304713 \\
\hline Leaves & 0.2488 & 0.092 & 13.55555556 & 5.4483744 \\
\hline Flowers & 0.2512 & 0.183 & 26.19444444 & 10.427725 \\
\hline Tender siliques & 0.2497 & 0.334 & 47.16666667 & 18.889334 \\
\hline seeds & 0.2535 & 0.168 & 24.11111111 & 9.5112864 \\
\hline $\begin{array}{l}\text { Mature } \\
\text { siliques }\end{array}$ & 0.2468 & 0.146 & 21.05555556 & 8.5314245 \\
\hline
\end{tabular}

\section{Discussion}

Flavonoids are a component rich in okra, with anti-cancer, cardiovascular protection, lower blood sugar and a series of efficacy [10]. Okra is being accepted in the pursuit of a balanced diet, healthy today. There are many varieties of okra grown in China, so it is necessary to detect and screen high yield and flavonoid content. Studies have shown that flavonoids in the various components of okra are relatively high [11]. Leaves, flowers and fruits in the highest content of flavonoids, however, the content of roots and stems especially mature roots and mature stems are relatively low. The results of determination show that the contents of tender seeds are higher than other parts of okra. The detection of flavonoids in the leaves was higher than the reported $1 \%$ [12], probably because the reported flavonoids were taken by RP-HPLC, and the method used in this paper was ethanol dissolved, and chlorophyll dissolved in ethanol may affect the accuracy of the test results. It is also necessary to develop flavors of flavonoids in various accessions and to develop other methods that are easy to be accepted by the drink. The content of flavonoids in different accessions was different. The highest flavonoids content in the seven accessions was JQK. Therefore, these results were very important for screening different accessions with good use.

Pectin is one of the components of the plant cell wall because of the role of cell adhesion, which is widespread between plants and cells. With the in-depth study of pectin, its function has been unearthed. In addition to daily vegetables, okra also has functions that anti-fatigue, protection of stomach and liver, improving the body immunity [13]. Pectin can be combined with cholesterol, diluted bile, the role of prevention of gallstones [14], so screening the content of pectin content of the application prospects are very broad. In this paper, the result of analyzing the dry powder of tender siliques collected from 7 accessions okra showed that the content of okra KLB and YGF were higher than other accessions, respectively, $21.71 \%$ and $20.61 \%$. In the dry powder analysis of different parts of MRZ found that the highest content of pectin content is tender siliques, $18.89 \%$. These data have important reference value in the subsequent screening of the high pectin content of okra. The tender siliques which have rich pectin are the main edible parts of the ingredients, indicating that the okra has a very high economic value in the subsequent development and utilization. In this study, the content of pectin from the seven

\section{Conclusion}

Okra is a kind of edible, health care and ornamental value of the economic crop, with a wide range of market value. In this paper, seven elements of okra, collected in Hebei, Shandong, Zhejiang and Jiangsu provinces, were analyzed and the genetic diversity was analyzed, which provided the basis for the identification of okra's accessions, cross breeding and development and utilization. Summarizing all the data in this paper, the following conclusions are gotten:

- The content of flavonoids in okra of different accessions was different. In this study, the flowers of YGF had the highest flavonoids content, $2.56 \%$. The content of tender siliques of JQK was the highest, $2.03 \%$. Moreover, there was a large difference in flavonoid content in different tissues of the same strain. The content of flavonoids in the stem of the MRZ was relatively low, especially $0.54 \%$ of the stem, and the tender seed had highest content of flavonoids, $3.14 \%$. These data can provide a basis for subsequent screening of different flavonoid accessions.

- During the experiment to detect all the okra accessions, all of okras were rich in pectin. The results showed that KLB had the highest content of pectin $21.73 \%$ in dry powder of tender siliques. Among 7 accessions, the tender siliques of HQK had the highest pectin content, reached $1.76 \%$. In the dry tissue of different accessions, tender siliques had the highest pectin content, $18.9 \%$. It is important for the 
selection of pectin in different okra accessions and these data can provide an important basis.

\section{Acknowledgments}

This research was supported by grants from National Key R\&D Program of China (2017YFF0210300), Key Research \& Development Project of Hunan Provincial Department of Science and Technology (2016WK2003), the National Key Laboratory of Plant Molecular Genetics (2015), National Natural Science Foundation of China (31540064, 31071076, 30871325), and Hunan Provincial Innovation Foundation for Postgraduate (CX2017B145, CX2016B097).

\section{References}

1. Xu D. Pectin on the prevention and treatment of common diseases. Jilin Med J. 2009;30(21):2715-16.

2. Cook NC, Samman S. Flavonoids-chemistry, metabolism, cardioprotective effects, and dietary sources. J Nutr Biochem. 1996;7(2):66-76.

3. Qian W, Xin B, Yang Y. Nutritional health care function and development prospect of okra. J Tradit Chin Med. 2016;(5):112-15.

4. Kuo SM, Leavitt PS, Lin CP. Dietary flavonoids interact with trace metals and affect metallothionein level in human intestinal cells. Biol Trace Elem Res. 1998;62(3):135-53.

5. Kerry H, Debra M. The structure, function, and biosynthesis of plant cell wall pectic polysaccharides. Carbohydr Res. 2009;344(14):1879-900.

6. Mohnen D. Pectin structure and biosynthesis. Curr Opin Plant Biol. 2008;11(3):266-77.

7. Vayssade $M$, Sengkhamparn $N$, Verhoef $R$, et al. Antiproliferative and proapoptotic actions of okra pectin on B16F10 melanoma cells. Phytother Res. 2010;24(7): 982-89.

8. Leclere L, Cutsem PV, Michiels C. Anti-cancer activities of pH- or heat-modified pectin. Front Pharmacol. 2013;4:128.
9. Liu X. Study on extraction technology and properties of Okra flower pectin polysaccharide. J Zhejiang Uni. 2014:7-8.

10. Van Dam RM, Naidoo N, Landberg R. Dietary flavonoids and the development of type 2 diabetes and cardiovascular diseases: review of recent findings. Curr Opin Lipidol. 2013;24(1):25-33.

11. Lin Y, Shi R, Wang X, et al. Luteolin, a flavonoid with potential for cancer prevention and therapy. Curr Cancer Drug Targets. 2008;8(7):634-46.

12. Lin $\mathrm{Y}, \mathrm{Lu} \mathrm{M}$, Liao H, et al. Content determination of the flavonoids in the different parts and different species of Abelmoschus esculentus $L$. by reversed phase-high performance liquid chromatograph and colorimetric method. Pharmacogn Mag. 2014;10(39):278.

13. Dong C, Liang S. The functional characteristics and comprehensive development and utilization of okra. Food Res Dev. 2007;28(5):180-82.

14. Terpstra AH, Lapre JA, De Vries HT, et al. The hypocholesterolemic effect of lemon peels, lemon pectin, and the waste stream material of lemon peels in hybrid $F_{1} B$ hamsters. Eur J Nutr. 2002;41(1):19-26.

\section{*Correspondence to:}

Guo X

State Key Laboratory of Chemo/Biosensing and

Chemometrics, College of Biology

Hunan University

Changsha 410082, PR China

E-mail: gxh@hnu.edu.cn

Ye J

College of Electrical and Information Engineering

Hunan University, 410082, PR China

E-mail: yjz@hnu.edu.cn 